\title{
Non-genomic actions of sex hormones on pregnant uterine contractility in rats: An in vitro study at term
}

\author{
Mohsen Mirdamadi ${ }^{\mathrm{a}}$, Anna Kothencz ${ }^{\mathrm{a}}$, Edina Szúcs ${ }^{\mathrm{b}}$, Sándor Benyhe ${ }^{\mathrm{b}}$, Mihály Szécsi ${ }^{\mathrm{c}}$, \\ Róbert Gáspár ${ }^{\mathrm{a}, *}$ \\ a Department of Pharmacology and Pharmacotherapy, Interdisciplinary Excellence Centre, Faculty of Medicine, University of Szeged, Hungary \\ ${ }^{\mathrm{b}}$ Institute of Biochemistry, Biological Research Center, Center of Excellence in European Union, Hungarian Academy of Sciences, Szeged, Hungary \\ ${ }^{\mathrm{c}}$ Department of Medicine, Faculty of Medicine, University of Szeged, Hungary
}

\section{A R T I C L E I N F O}

\section{Keywords:}

Sex hormones

Mifepristone

Non-genomic pathway

Myometrial contraction

Pregnancy

Rat

\begin{abstract}
A B S T R A C T
Aims: The non-genomic (prompt) actions of sex steroids on pregnant uterine contractility are not fully explored yet, the aim of our study was to clarify such effects of $17-\beta$ estradiol (E2), progesterone (P4) and testosterone (T) on late (22-day) pregnant uterine contractions together with the signaling pathways in rats in vitro.

Methods: The uterine effects of sex steroids on KCl-stimulated contractions were examined in the presence of genomic pathway blocker actinomycin D and cycloheximide, sex hormone receptor antagonists (flutamide, fulvestrant, mifepristone) and also after removing the endometrium. The modifications in uterine G-protein activation and cAMP levels were also detected.

Results: $\mathrm{T}$ and $\mathrm{E} 2$ both relaxed the uterine contractions in the concentration range of $10^{-8}-10^{-3} \mathrm{M}$ with an increase in the activated G-protein and cAMP levels of the uterus, while P4 was ineffective. Cycloheximide, actinomycin D, antagonist for T and E2 were not able to modify the responses along with the endothelium removal. Mifepristone blocked the relaxing effects of T and E2 and reduced the activation of G-protein and the formation of cAMP.

Significance: T and E2 can inhibit KCl-stimulated contractions in the late pregnant uterus in high concentrations and in a non-genomic manner. Their actions are mediated by a G-protein coupled receptor that can be blocked by mifepristone. A single and high dose of $\mathrm{T}$ or $\mathrm{E} 2 \mathrm{might}$ be considered in premature contractions, however, further preclinical and clinical studies are required for the approval of such a therapeutic intervention.
\end{abstract}

\section{Introduction}

Sex hormones mediate a wide range of developmental processes and physiological functions, especially in reproductive organs. Sex hormones can even influence pregnant uterine contractility; their ratio may be an important key in the parturition process. Progesterone is wellknown as a pro-gestational hormone reducing uterine contractility and maintaining pregnancy [1]. On the other hand, estrogens increase the contraction of the pregnant uterus and contribute to the parturition process [2]. However, the effect of testosterone (T) on pregnancy has not exactly been clarified yet, it is presumed to increase the rate of miscarriage [3].

The classical signaling pathway of steroids is the "genomic pathway". Steroids first pass the membrane, bind to specific steroid receptors and make a ligand-receptor complex, which goes into the nucleus; then, by binding to the hormone response element or functional proteins like nuclear factor kappa B, they alter gene transcription and protein synthesis [4]. This action has a significant gap time between the drug administration or the secretion of hormones and the desired effect.

However, there is prompt action for all types of steroids which occurs immediately (without a significant gap time) called "non-genomic pathway". One of the first studies about the non-genomic action of sex steroids demonstrated that immediately after the administration of $17-\beta$ estradiol (E2) to ovariectomized rat, the level of uterine cyclic adenosine monophosphate (cAMP) was doubled [5]. Several other studies showed that sex hormones exert a variety of prompt functional effects on different tissues, such as cancer cells in breast [6], pituitary glands [7], sperms [8], nerve cells [9] and many other targets.

It is known that the results of the non-genomic action can be the

\footnotetext{
* Corresponding author at: Department of Pharmacology and Pharmacotherapy, Interdisciplinary Excellence Centre, Faculty of Medicine, University of Szeged, Hungary, Szeged 6720, Hungary.

E-mail address: gaspar.robert@med.u-szeged.hu (R. Gáspár).
} 
same as or even different from the effects mediated through the genomic pathway. E.g. in the cardiovascular system and diabetes mellitus, the outcome of both signaling pathways is the same [10-13], but in breast cancer cell lines, their actions can be the opposite [14].

Since the prompt actions of sex steroids on uterine contractility are not fully explored yet, the aim of our study was to clarify the nongenomic effects of E2, progesterone (P4) and T on late (22-day) pregnant uterine contractions together with the signaling pathways in rats in vitro.

\section{Materials and methods}

\subsection{Animals}

Housing, handling, and mating of animals were performed as described previously [15]. In brief, 22-day-pregnant Sprague Dawley (SPRD) rats were chosen for the experiment, they were housed in the animal facility of the Department of Pharmacology and Pharmacotherapy, Faculty of Medicine, University of Szeged under controlled temperature, humidity and light $\left(20-23{ }^{\circ} \mathrm{C}\right.$ and $40-60 \%$ and $12 \mathrm{~h}$ light/ dark regime, respectively). The animals were kept on a standard $\mathrm{Al}-$ tromin 1324 rodent pellet diet (Charles-River Laboratories, Sulzfeld, Germany), with tap water available ad libitum.

Mature female rats (180-200 g) in estrus cycle were chosen by vaginal impedance with Estrus Cycle Monitor (Fine Science Tools, Foster City, CA, USA), the selected females and stud male rats (240-260 g) were placed separately in special breeding cages separated by an automated movable gate. The gate was pulled up at 4 am and the mating was possible within 4-5 h. To confirm the intercourse, the native vaginal smear or copulation plugs were evaluated. The positive cases were housed in separate cages and considered as on the first day of pregnancy.

This project was approved by the Hungarian Ethical Committee for Animal Research (Permission number: IV./13071/2016). The animals were treated in accordance with the European Communities Council Directive (86/609/ECC) and the Hungarian Act for the Protection of Animals in Research (Article 32 of Act XXVIII).

\subsection{Isolated organ bath contractility studies}

The experimental protocol is shown in Fig. 1. The animals were terminated in a carbon dioxide chamber and the uterus samples were cut from both sides of the uterine horns. After cleaning from connective and adipose tissue, 3-4-mm dissected uterine tissues were tied with silk thread and mounted vertically in isolated organ bath filled with $10 \mathrm{ml}$ de Jongh buffer consisting of 137 millimolar (mM) NaCl, $3 \mathrm{mM} \mathrm{KCl}$, $1 \mathrm{mM} \mathrm{CaCl}, 1 \mathrm{mM} \mathrm{MgCl} 2,12 \mathrm{mM} \mathrm{NaHCO}, 4 \mathrm{mM} \mathrm{NaH}_{2} \mathrm{PO}_{4}, 6 \mathrm{mM}$ glucose, the $\mathrm{pH}$ was adjusted between 7.35 and 7.40 with constant temperature $\left(37{ }^{\circ} \mathrm{C}\right)$ and with carbogen $\left(95 \% \mathrm{O}_{2}+5 \% \mathrm{CO}_{2}\right)$ support. Tissues were attached to a gauge transducer (SG-02; MDE GmBH., Heidelberg, Germany), with initial resting tension of $1.5 \mathrm{~g}$, the contractions were measured, recorded and analyzed with a SPEL Advanced ISOSYS Data Acquisition System (MDE GmBH., Heidelberg, Germany). The tissues were washed periodically every 15 min during the 1-h equilibrium incubation period.

To achieve a satisfactory rhythmic contraction response, $\mathrm{KCl}$ (25 $\mathrm{mM}$ ) was added to each chamber for $7 \mathrm{~min}$. Each steroid was added in a cumulative way ( $\mathrm{T}, \mathrm{E} 2, \mathrm{P} 4)\left(10^{-8}-10^{-3} \mathrm{M}\right)$ every $5 \mathrm{~min}$. Concentration-response curves were plottedagainst the KCl-stimulated contraction response and the effects of steroids were expressed in percentage change.

In another set of experiments, uterine tissues were pre-treated with cycloheximide $\left(10^{-6} \mathrm{M}\right)$, a protein synthesis inhibitor and actinomycin D $\left(10^{-6} \mathrm{M}\right)$, a transcriptional inhibitor for 2 steroids (E2 and testosterone) separately for $30 \mathrm{~min}$. Tissues were pre-treated with the following steroid hormone receptor antagonists for $10 \mathrm{~min}$ before $\mathrm{KCl}$ stimulation: fulvestrant $\left(10^{-6} \mathrm{M}\right)$ for E2, flutamide $\left(10^{-6} \mathrm{M}\right)$ for $\mathrm{T}$ and mifepristone $10^{-6} \mathrm{M}$ for all types of steroids.

Finally, the endometrium of the uterine tissues was removed by scraping and the experiments were repeated to observe the effect of the steroids on the myometrium. The experimental protocol of the isolated organ bath study is shown in Fig. 1 .

The samples for each experiment were collected from both sides of the uterine horns of 2 animals ( 8 rings/experiment) and repeated at least 3 times for each individual set of experiments $(n=60)$.
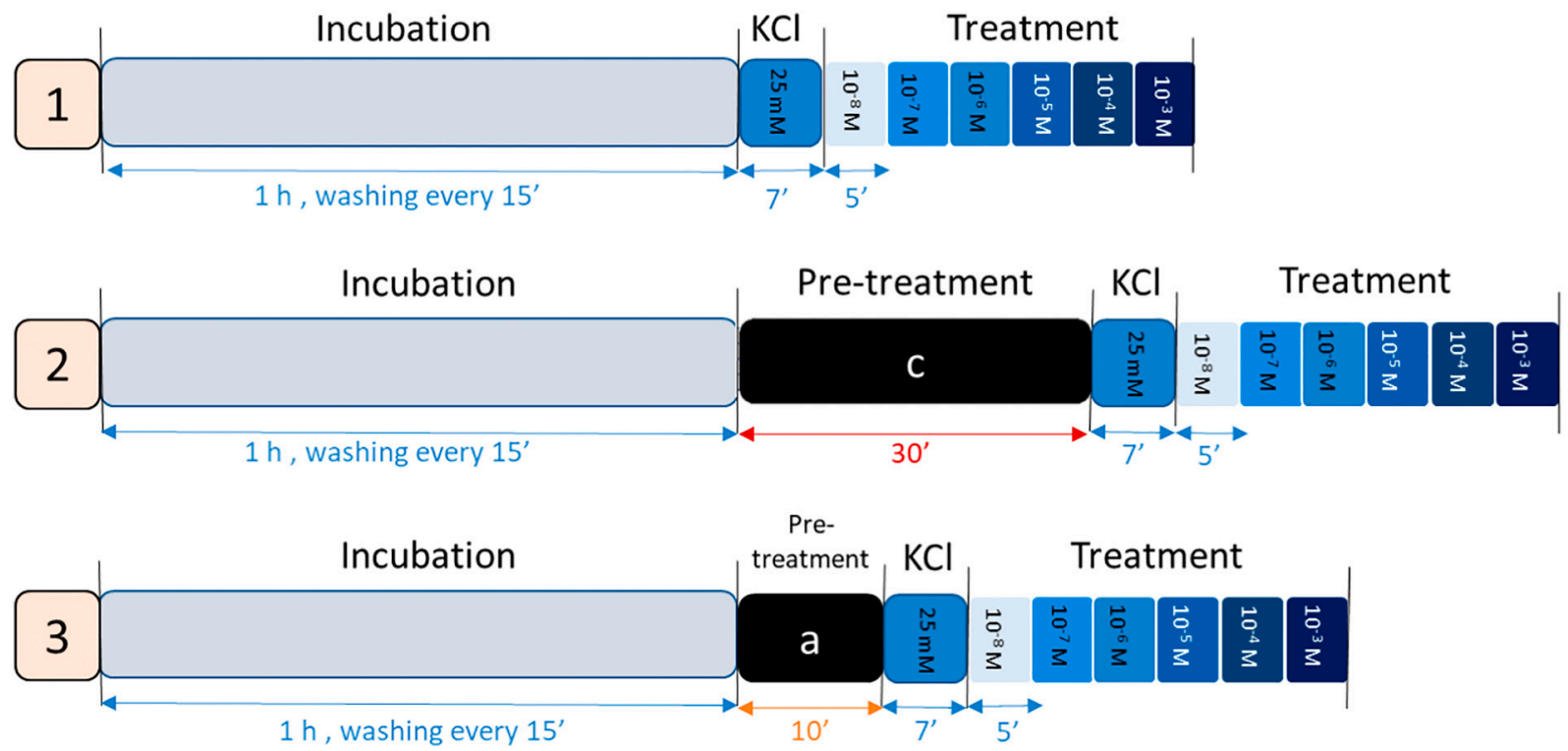

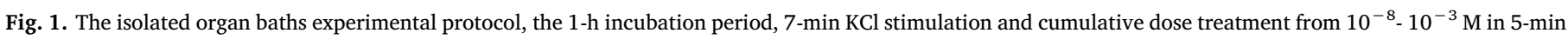

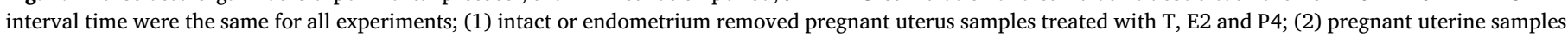

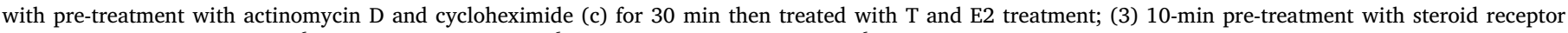
antagonist (a): fulvestrant $10^{-6} \mathrm{M}$ for E2, flutamide $10^{-6} \mathrm{M}$ for T and mifepristone $10^{-6} \mathrm{M}$ for all steroid treatments, then treatment with $\mathrm{T}$, E2 and P4. 

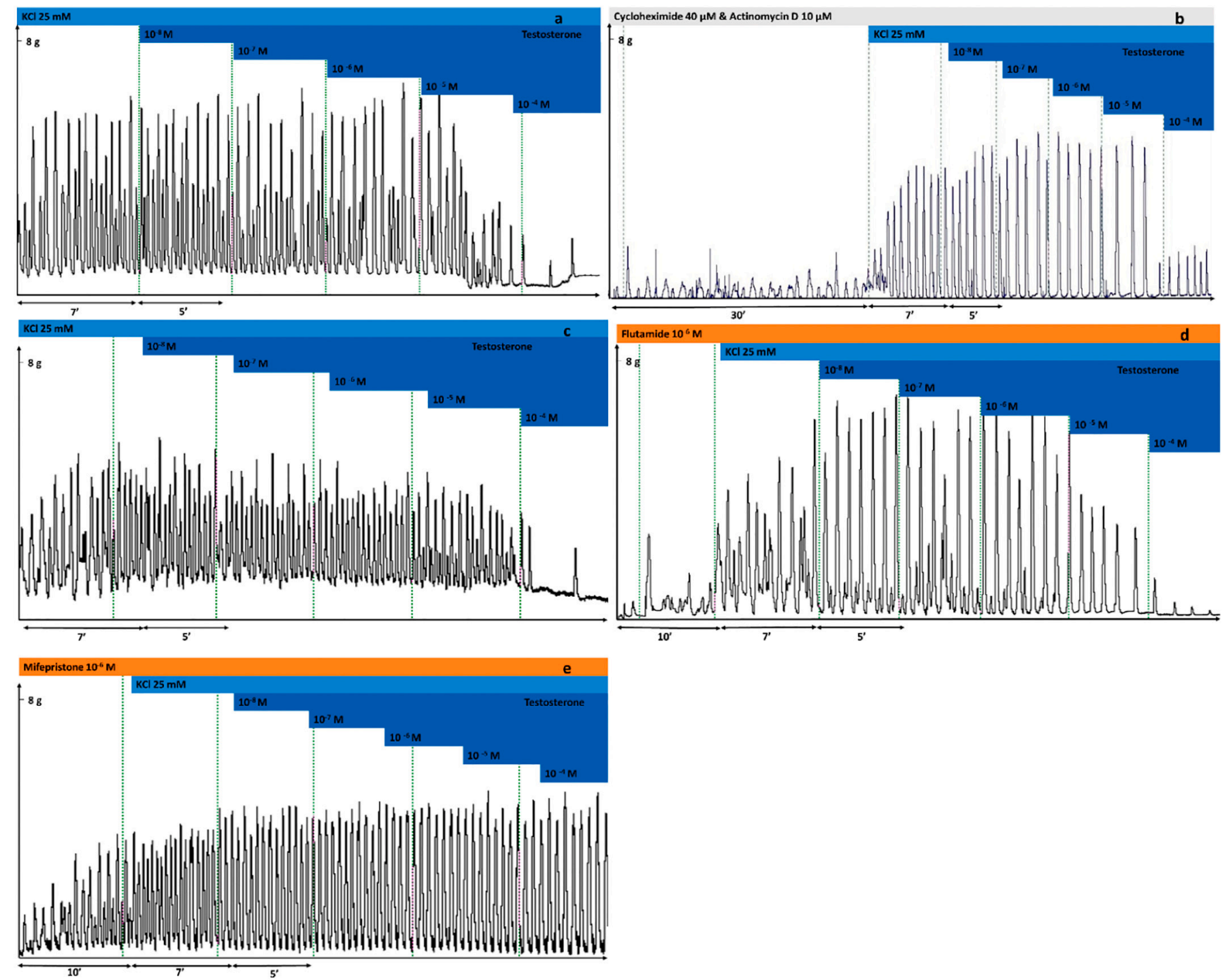

Fig. 2. Effects of testosterone (T) on KCl-induced $(25 \mathrm{mM})$ uterine contractions at concentrations of $10^{-8}-10^{-4} \mathrm{M}$ in a cumulative manner. Contraction was induced in the uterine rings prepared from rats on gestational day 22. Each figure is a representative record. (a) Effect of $\mathrm{T}$ after stimulation with $\mathrm{KCl}$, (b) after 30 min of actinomycin D and cycloheximide pre-treatment, (c) after endometrium removal, (d) with pre-treatment with flutamide $10^{-6} \mathrm{M}$ and (e) with pre-treatment with mifepristone $10^{-6} \mathrm{M}$.

\section{3. $\left[{ }^{35} S\right] G T P \gamma S$ studies}

The $\left[{ }^{35} \mathrm{~S}\right] \mathrm{GTP} \gamma \mathrm{S}$ binding experiments protocol was carried outby the previously described method [16] with modifications. Briefly, the pregnant uterine tissue samples from SPRD rats $(n=5)$ were collected and stored at $-70{ }^{\circ} \mathrm{C}$ before preparation. The samples were ground, then homogenized with 20 volumes $(W / V)$ of ice-cold Tris-EDTA buffer (composed of $10 \mathrm{~mm}$ Tris- $\mathrm{HCl}, 1 \mathrm{mM}$ EDTA, $0.6 \mathrm{mM} \mathrm{MgCl}_{2}$, and $0.25 \mathrm{M}$ sucrose, $\mathrm{pH}$ 7.4) with Ultra-Turrax ${ }^{\circledR}$ (IKA-Werke $\mathrm{GmbH}$ \& Co. KG, Staufen in Breisgau, Germany) homogenizer in an ice bath for $2 \times 30 \mathrm{~s}$, after that suspended with 4-layer gauze filter, then centrifuged at $40000 \mathrm{~g}$ for $20 \mathrm{~min}$ at $4{ }^{\circ} \mathrm{C}$. Later the pellets were suspended in 5 volumes of buffer. The protein content was measured by a Nanodrop ${ }^{\mathrm{TM}}$ 2000 spectrophotometer (Thermo Fisher Scientific, Wilmington, US) and diluted to $10 \mathrm{mg} / \mathrm{ml}$ sample.

Samples were pre-incubated in the final volume of $900 \mu \mathrm{l}$ of TrisEGTA buffer (pH 7.4) composed of 50 mM Tris-HC, 1 mM EGTA, 3 mM $\mathrm{MgCl}_{2}, 100 \mathrm{mM} \mathrm{NaCl}$, containing $20 \mathrm{mbq} / 0.05 \mathrm{~cm}^{3}\left[{ }^{35} \mathrm{~S}\right] \mathrm{GTP} \gamma \mathrm{S}$ $(0.05 \mathrm{~nm})$ without or with mifepristone $\left(10^{-6} \mathrm{M}\right)$ for $15 \mathrm{~min}$ in $30^{\circ} \mathrm{C}$. After that, E2 and T were added separately to each tube in an increasing dose $\left(10^{-8}-10^{-4}\right)$ for $20 \mathrm{~min}$. The total binding was measured without drugs. Nonspecific binding was evaluated by $10 \mu \mathrm{m}$ unlabeled GTP $\gamma \mathrm{s}$ and differences from total binding (basal activity).After the incubation time, by using vacuum filtration (through Whatman GF/B filters with Brandel M24R Cell harvester), the bound and free $\left[{ }^{35} \mathrm{~S}\right] \mathrm{GTP} \gamma \mathrm{S}$ were

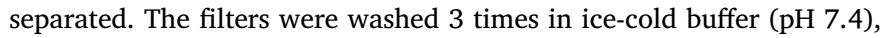
the radioactivity of the filters was measured in Ultimagold ${ }^{\mathrm{TM}} \mathrm{MV}$ scintillation cocktail with Packard Tricarb 2300TR liquid scintillation counter. The experiment was arranged in triplicates and repeated three times.

\subsection{Cyclic AMP studies}

The cyclic AMP (cAMP) level in uterine tissues was measured by a commercial cAMP Enzyme Immunoassay Kit (Cayman Chemical, USA). Uterine tissue samples of 22-day-pregnant SPRD rats $(n=8)$ were incubated in an organ bath filled with de Jongh buffer. The samples were incubated without or with mifepristone $\left(10^{-6} \mathrm{M}\right)$ for $10 \mathrm{~min}$, and $\mathrm{KCl}$ $25 \mathrm{mM}$ was added for further $7 \mathrm{~min}$. Then $\mathrm{E} 2$ and $\mathrm{T}$ or control (vehicle) were added in 2 different doses $\left(10^{-4}\right.$ and $\left.10^{-6} \mathrm{M}\right)$ for $5 \mathrm{~min}$, and forskolin $\left(10^{-5} \mathrm{M}\right)$ was added for another $10 \mathrm{~min}$. Finally, the samples were snap frozen by liquid nitrogen and stored at $-70{ }^{\circ} \mathrm{C}$ for sample 


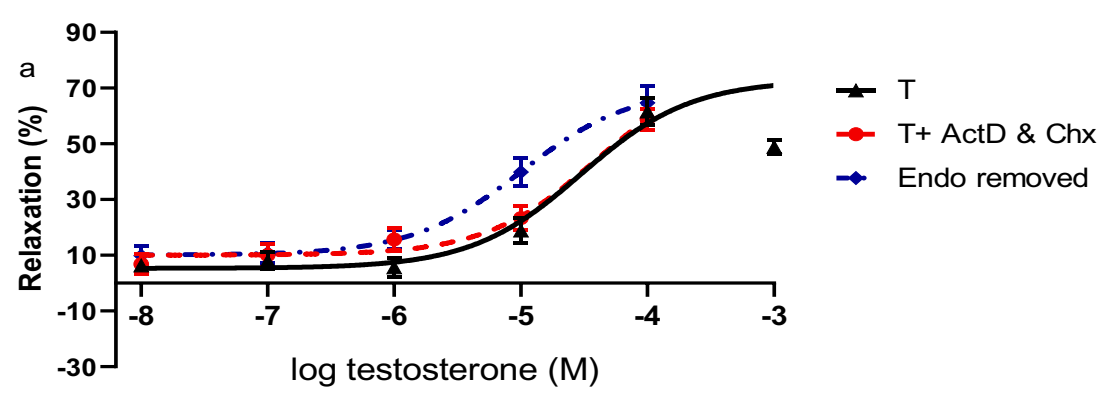

Fig. 3. Effects of $\mathrm{T}$ on pregnant uterine contractions stimulated with $\mathrm{KCl}(25 \mathrm{mM})$ and pre-treated with actinomycin D and cycloheximide, and after endometrium removal (a), and with pre-treatment with flutamide or mifepristone (b) presented by percent of relaxation. $* *: p<0.01$; $* * *$ : $p<0.001$; ActD, actinomycin D; Chx, cycloheximide; Endo, endometrium; Flu, flutamide; Mif, mifepristone; T, testosterone.

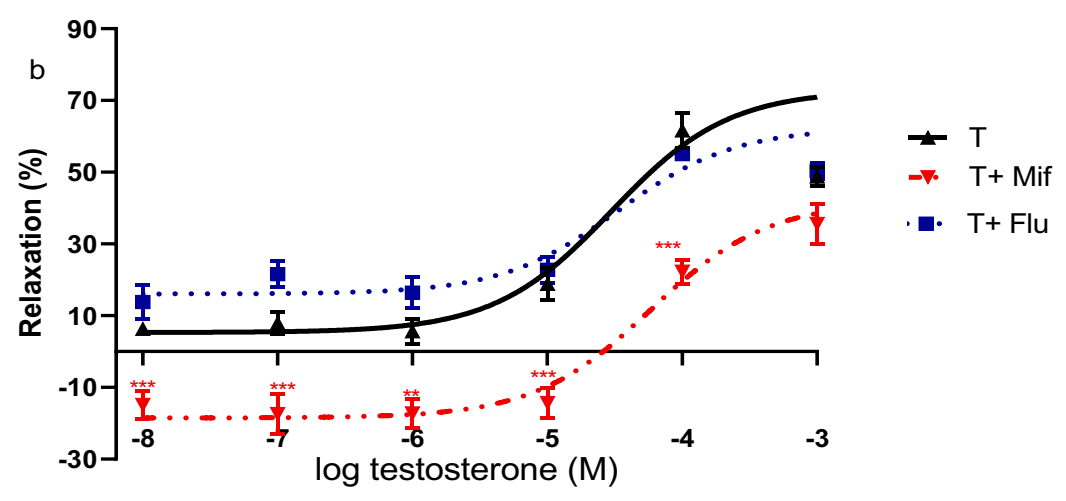

Table 1

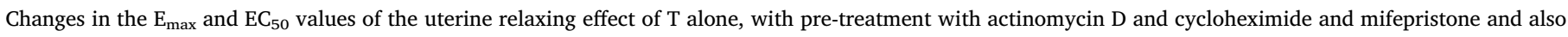

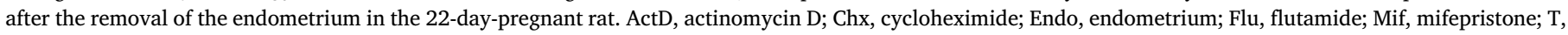
testosterone.

\begin{tabular}{|c|c|c|c|c|c|}
\hline & $\mathrm{T}$ & $\mathrm{T}+\mathrm{ActD}+\mathrm{Chx}$ & $\mathrm{T}+\mathrm{FLU}$ & $\mathrm{T}+$ Mif & Endo removal \\
\hline $\mathrm{E}_{\max }(\% \pm$ S.E.M $)$ & $72.9 \pm 7.8$ & $77.4 \pm 2.4$ & $62.4 \pm 8$ & $41.9 \pm 7.2$ & $70.2 \pm 2.7$ \\
\hline $\mathrm{EC}_{50}(\mathrm{M})$ & $3.0 e-005$ & $3.8 e-005$ & $3.3 e-005$ & $5.8 \mathrm{e}-005^{\text {***:* }}$ & $1.0 \mathrm{e}-005$ \\
\hline
\end{tabular}

*** $\mathrm{p}<0.001$.

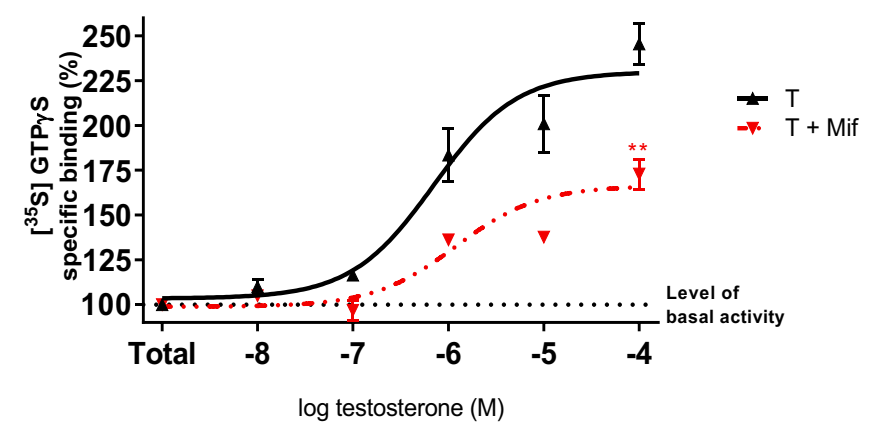

Fig. 4. Effect of $\mathrm{T}\left(10^{-8}-10^{-4} \mathrm{M}\right)$ on $\left.{ }^{35} \mathrm{~S}\right] \mathrm{GTP} \gamma \mathrm{S}$ binding with or without pretreatment with mifepristone. Mifepristone reduced the T-induced increase in $\left[{ }^{35} \mathrm{~S}\right] \mathrm{GTP} \gamma \mathrm{S}$ binding. Basal activity $(100 \%)$ refers to the level of $\left[{ }^{35} \mathrm{~S}\right] \mathrm{GTP} \gamma \mathrm{S}$ binding without any substances. ${ }^{* *}: p<0.01$; Mif, mifepristone; $\mathrm{T}$, testosterone.

preparation. During the preparation frozen tissues were weighed, pulverized, mixed and homogenized with 10 volumes of $5 \%$ trichloroacetic acid (TCA) aqueous solution $\left(0-4{ }^{\circ} \mathrm{C}\right)$, and centrifuged at $1500 \mathrm{~g}$ for $15 \mathrm{~min}$. The supernatants were mixed with 5 volumes of water-saturated ether and shaken in $10 \mathrm{~s}$ to extract TCA from it, the ether supernatant was removed, discarded and this process was repeated 3 times. Finally, after removing all the ether by heating, the liquid samples were stored at $-70{ }^{\circ} \mathrm{C}$ till the cAMP assay was carried out. The amounts of cAMP were expressed in $\mathrm{nmol} / \mathrm{mg}$ tissue.
Table 2

Changes in the $\left[{ }^{35} \mathrm{~S}\right] \mathrm{GTP} \gamma \mathrm{S}$ binding induced by $\mathrm{T}$ alone and with pre-incubation with mifepristone in the 22-day-pregnant rat uteri. Mif, mifepristone; T, testosterone.

\begin{tabular}{lll}
\hline & $\mathrm{T}$ & $\mathrm{T}+\mathrm{Mif}$ \\
\hline $\mathrm{E}_{\max }(\% \pm$ S.E.M $)$ & $230 \pm 9.3$ & $166 \pm 7.2^{* *}$ \\
$\mathrm{EC}_{50}(\mathrm{M})$ & $7 \mathrm{e}-007$ & $1.2 \mathrm{e}-006$ \\
\hline
\end{tabular}

${ }^{* *} p<0.01$.

\subsection{Drugs and chemicals}

1,3,5-Estratriene-3,17ß-diol (E2), 4-pregnene-3,20-dion (P4), 17ßHydroxy-3-oxo-4-androstene (T), cycloheximide, actinomycin D, mifepristone and flutamide were all purchased from Sigma-Aldrich, Budapest, Hungary. Fulvestrant (Falsoldex) $250 \mathrm{mg} / \mathrm{ml}$ injection was purchased from AstraZeneca Pharmaceutical, Budapest, Hungary. Forskolin was purchased from Tocris, Norderstedt, Germany.

All the drugs were dissolved in ethanol $97 \%$, the highest percentage of the solvent did not exceed $0.087 \% \mathrm{~V} / \mathrm{V}$.

\subsection{Statistical analysis}

Concentration-response curves were fitted by the analysis of the areas under curve (AUC) of contractility responses. Statistical analysis was carried out by the Prism 8.0 (GraphPad Software Inc. San Diego, CA, USA) computer program using ANOVA Dunnett's test. The $\mathrm{E}_{\max }$ and $\mathrm{EC}_{50}$ values were calculated based on AUC. The results are presented as 


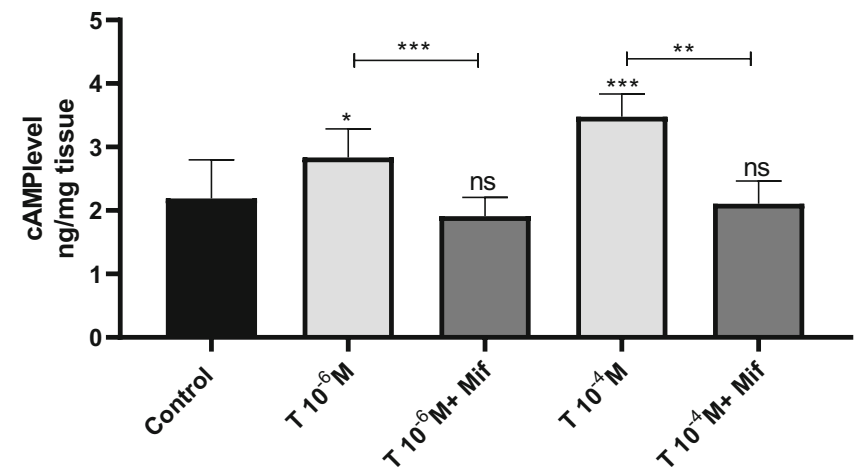

Fig. 5. Change in the level of uterine cAMP in the presence of $\mathrm{T}$ alone and after pre-treatment with mifepristone. The uterine cAMP level was expressed in ng/ mg tissue. ${ }^{*}: p<0.05 * *: \mathrm{p}<0.01 ; * * *: p<0.001$; Mif, mifepristone; $\mathrm{T}$, testosterone. the mean \pm SEM.

\section{Results}

\subsection{Testosterone}

3.1.1.1. Isolated organ bath study. T elicited a relaxing effect especially at high concentrations $\left(10^{-5}-10^{-3} \mathrm{M}\right)$ and reached $70 \%$ relaxation of the uterus (Figs. 2a, 3a, Table 1). The presence of cycloheximide and actinomycin D (Figs. 2b, 3b, Table 1), the removal of the endometrium (Figs. 2c, 3b, Table 1) or even flutamide did not modify the relaxing effect of $\mathrm{T}$. However, mifepristone shifted the $\mathrm{T}$ concentration-response curve to the right and reduced its maximal inhibitory effect. In the subsequent experiments investigating the signaling pathway, we measured the $\mathrm{T}$ action alone or in the presence of mifepristone. The interventions (endometrium removal) and drug treatments (actinomycin D, cycloheximide, flutamide) with non-significant modifications were omitted from further studies.

3.1.1.2. $\left[{ }^{35} S\right] G T P \gamma$ s binding assay studies. T increased the $\left[{ }^{35} \mathrm{~S}\right] \mathrm{GTP} \gamma \mathrm{S}$
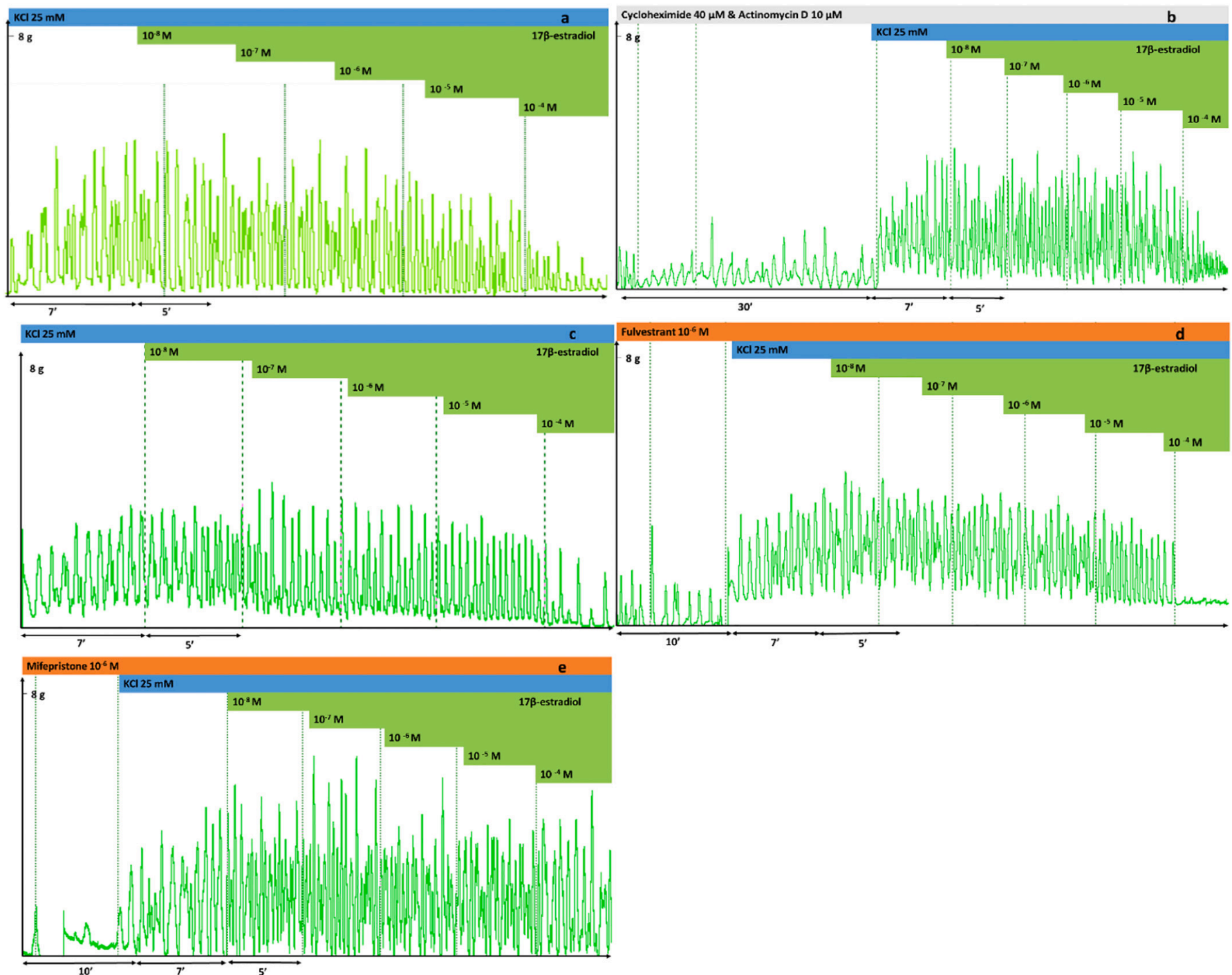

Fig. 6. Effects of $17 \beta$-estradiol (E2) on KCl-induced uterine contractions at concentrations of $10^{-8}$ to $10^{-4} \mathrm{M}$ in a cumulative manner. Contraction was induced by $\mathrm{KCl}(25 \mathrm{mM})$ in the uterine rings prepared from rats on gestational day 22. Each figure is a representative record. (a) Effect of E2 after $7 \mathrm{~min}$ of stimulation with KCl, (b) after 30 min of actinomycin D and cycloheximide pre-treatment, (c) after endometrium removal, (d) with pre-treatment with fulvestrant $10^{-6} \mathrm{M}$ and (e) with pretreatment with mifepristone $10^{-6} \mathrm{M}$. 


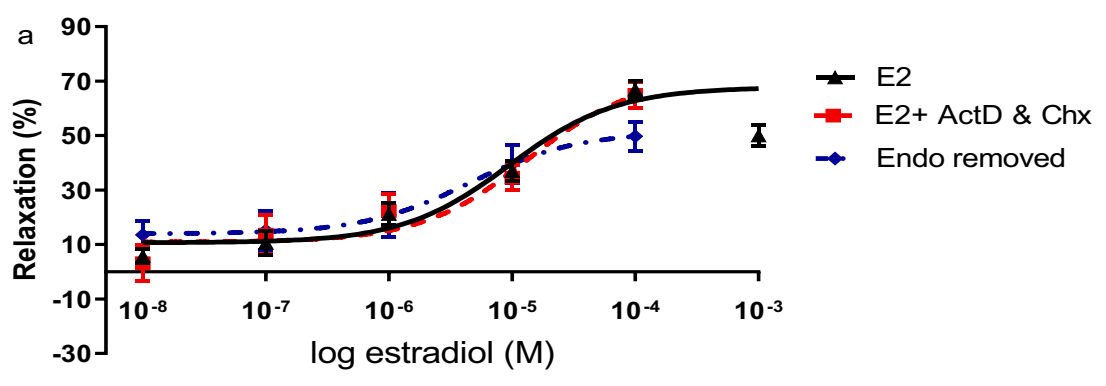

Fig. 7. Effect of E2 on pregnant uterus tissue stimulated with $\mathrm{KCl}(25 \mathrm{mM})$ in the presence of actinomycin D and cycloheximide (a), and with pre-treatment with fulvestrant or mifepristone, and after endometrium removal (b) presented by percent of relaxation. ${ }^{*} p<0.05 * * p<0.01 ; * * *$ : $p<0.001$; ActD, actinomycin D; Chx, cycloheximide; E2, $17-\beta$ estradiol; Mif, mifepristone; Ful, fulvestrant.

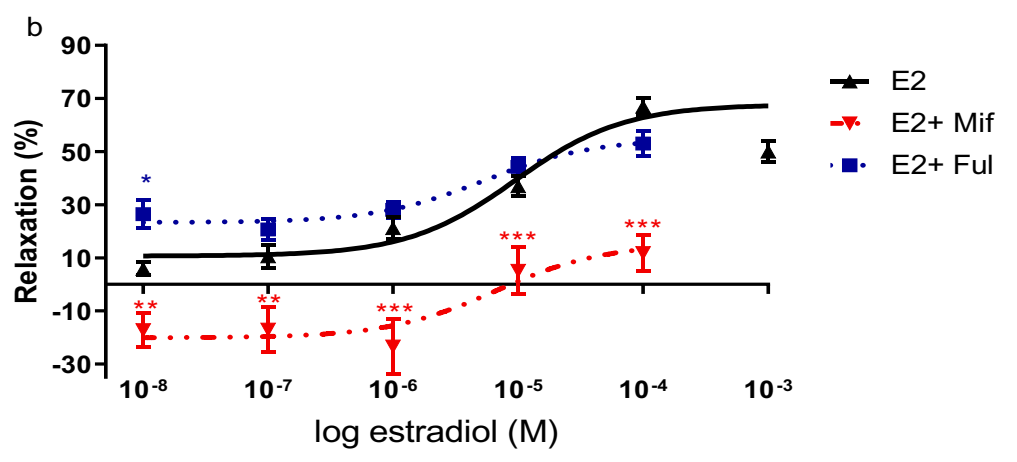

Table 3

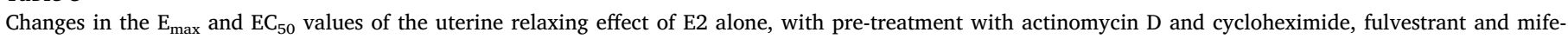
pristone and after removing the endometrium. ActD, actinomycin D; Chx, cycloheximide; E2, 17- $\beta$ estradiol; Ful, fulvestrant; Mif, mifepristone.

\begin{tabular}{|c|c|c|c|c|c|}
\hline & $\mathrm{E} 2$ & $\mathrm{E} 2+\mathrm{ActD}+\mathrm{Chx}$ & $\mathrm{E} 2+\mathrm{Ful}$ & $\mathrm{E} 2+\mathrm{Mif}$ & Endo removal \\
\hline $\mathrm{E}_{\max }(\% \pm$ S.E.M $)$ & $67.8 \pm 2.8$ & $71.7 \pm 3.8$ & $54.8 \pm 2.9$ & $15.4 \pm 5.5^{* * * *}$ & $51.3 \pm 4.6$ \\
\hline $\mathrm{EC}_{50}(\mathrm{M})$ & $9.5 e-006$ & $1.3 e-005$ & $5.3 e-006$ & $6.7 e-006$ & $4.6 e-006$ \\
\hline
\end{tabular}

**** $\mathrm{p}<0.001$

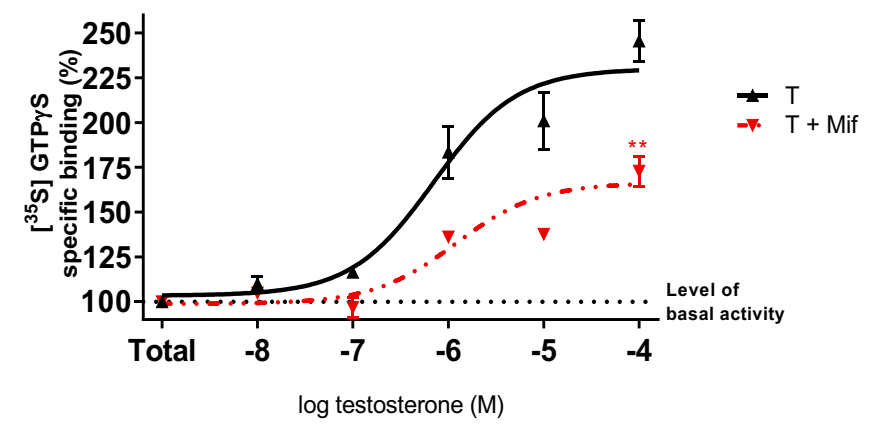

Fig. 8. The effect of E2 $\left(10^{-8}-10^{-4} \mathrm{M}\right)$ on $\left[{ }^{35} \mathrm{~S}\right] \mathrm{GTP} \gamma \mathrm{S}$ binding with or without pre-treatment with mifepristone. Mifepristone reduced the E2-induced increase in $\left[{ }^{35} \mathrm{~S}\right] \mathrm{GTP} \gamma \mathrm{S}$ binding. Basal activity $(100 \%)$ refers to the level of $\left[{ }^{35} \mathrm{~S}\right] \mathrm{GTP} \gamma \mathrm{S}$ binding without substance. ${ }^{* *}: p<0.01$; E2, 17- $\beta$ estradiol; Mif, mifepristone.

Table 4

Changes in the $\left[{ }^{35} \mathrm{~S}\right] \mathrm{GTP} \gamma \mathrm{S}$ binding effect of $\mathrm{E} 2$ alone and with pre-incubation with mifepristone in the 22-day-pregnant rat. E2, 17- $\beta$ estradiol; Mif, mifepristone.

\begin{tabular}{lll}
\hline & $\mathrm{E} 2$ & $\mathrm{E} 2+\mathrm{Mif}$ \\
\hline $\mathrm{E}_{\max }(\% \pm$ S.E.M $)$ & $196.3 \pm 7.7$ & $155 \pm 4.5$ \\
$\mathrm{EC}_{50}(\mathrm{M})$ & $7.1 \mathrm{e}-007$ & $8.5 \mathrm{e}-007$
\end{tabular}

${ }^{* *} \mathrm{p}<0.01$

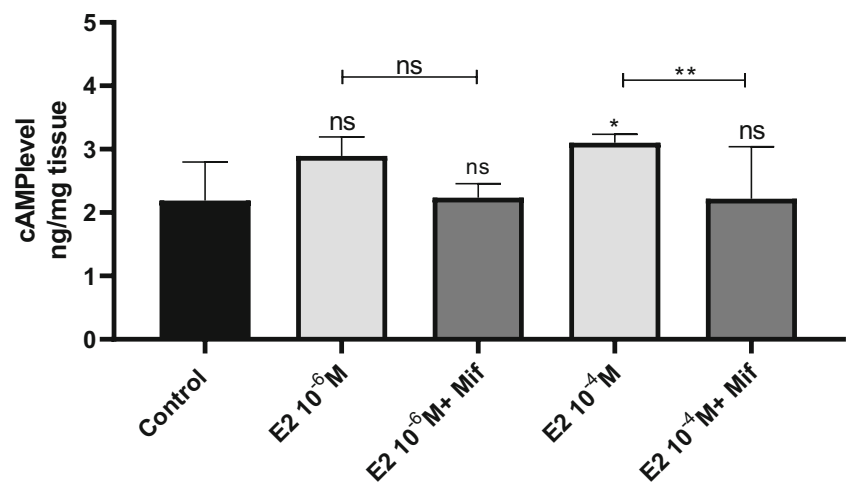

Fig. 9. Changes in the level of cAMP in the presence of E2 alone $\left(10^{-6}\right.$ and $\left.10^{-4} \mathrm{M}\right)$ and with pre-treatment with mifepristone expressed in $\mathrm{ng} / \mathrm{mg}$ tissue. $*: p<0.05 * *: \mathrm{p}<0.01$; E2, 17- $\beta$ estradiol; Mif, mifepristone.

binding in a concentration dependent manner. The pre-treatment with mifepristone reduced specific binding and shifted the curve to the right, indicating less activation of G-proteins (Fig. 4 and Table 2).

3.1.1.3. cAMP study. The pregnant uterus cAMP level was raised by $\mathrm{T}$ compared to the control at both low and high concentrations $\left(10^{-6}\right.$ and $10^{-4} \mathrm{O}$. Moreover, the pre-treatment with mifepristone significantly reduced the uterine cAMP levels by $\mathrm{T}$ (Fig. 5).

\section{2. $17-\beta$ estradiol}

Isolated organ bath study: E2 relaxed pregnant uterine contractions, 

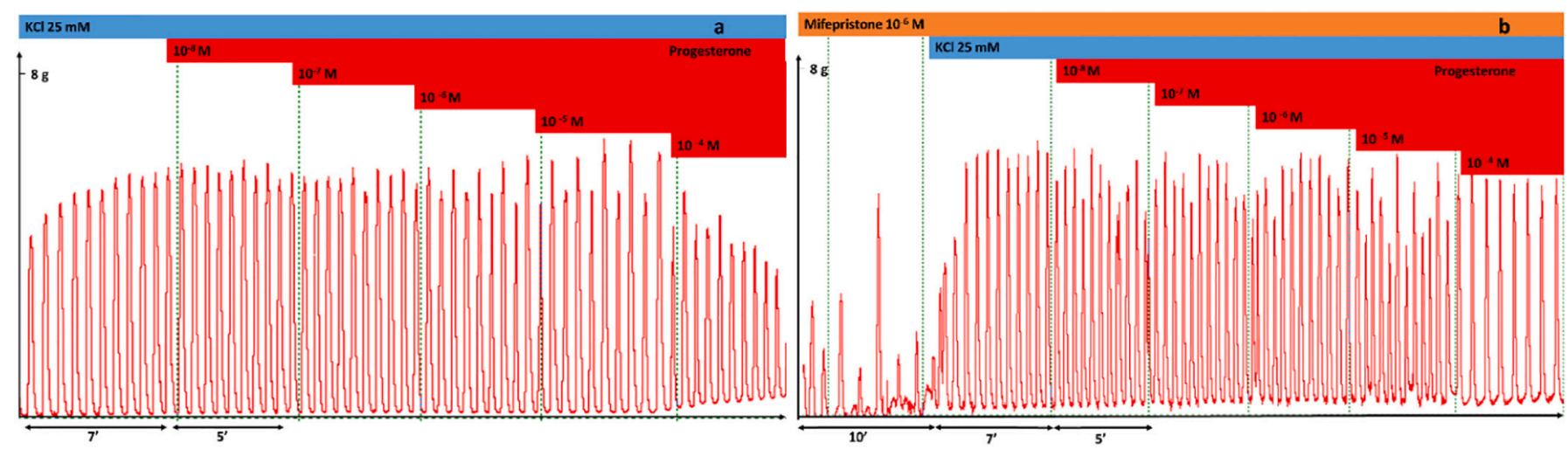

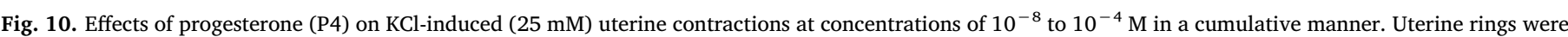

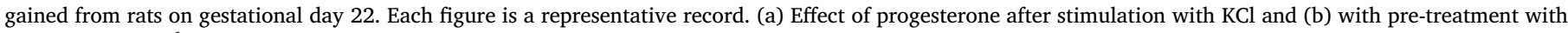
mifepristone $10^{-6} \mathrm{M}$.

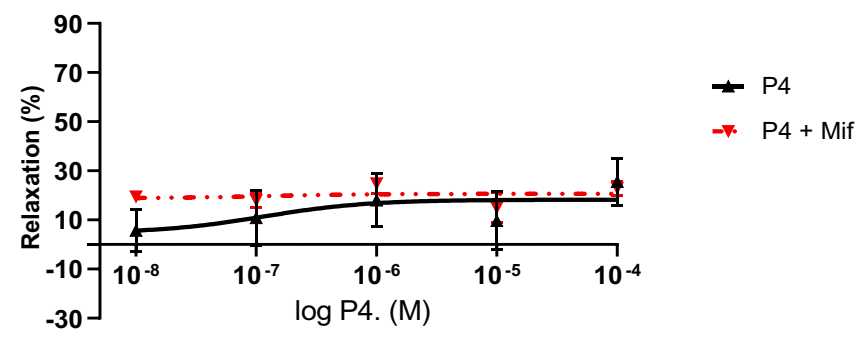

Fig. 11. Effect of P4 on pregnant uterus smooth muscle contractions stimulated by $\mathrm{KCl}$, alone and in the presence of mifepristone. Mif, mifepristone; P4, progesterone.

Table 5

Changes in the uterine-contracting effect of $\mathrm{P} 4$ alone and in the presence of mifepristone. P4; progesterone. Mif, mifepristone;

\begin{tabular}{lll}
\hline & $\mathrm{P} 4$ & $\mathrm{P} 4+\mathrm{Mif}$ \\
\hline $\mathrm{E}_{\max }(\% \pm$ S.E.M $)$ & $16.8 \pm 6.9$ & $20.6 \pm 2.6$ \\
$\mathrm{EC}_{50}(\mathrm{M})$ & $1.2 \mathrm{e} 007$ & $1.2 \mathrm{e}-007$
\end{tabular}

at the highest concentration $\left(10^{-4} \mathrm{M}\right)$, the inhibition was $70 \%$ (Figs. 6 , 7a, Table 3). Actinomycin D and cycloheximide (Figs. 6b, 7a, Table 3), the removal of the endometrium (Figs. $6 \mathbf{c}, 7 \mathrm{a}$, Table 3 ) or even pretreatment with fulvestrant, (Figs. $6 \mathrm{~d}, 7 \mathrm{~b}$, Table 3 ) did not influence the effect of E2. In contrast, pre-treatment with mifepristone reduced the relaxing effect of $\mathrm{E} 2$, but did not modify the $\mathrm{EC}_{50}$ value (Figs. $6 \mathrm{e}, 7 \mathrm{~b}$, Table 3). In the subsequent experiments investigating the signaling pathway, we measured the E2 action alone or in the presence of mifepristone. The interventions (endometrium removal) and drug treatments (actinomycin D, cycloheximide, flutamide) with non-significant modifications were omitted from further studies.

3.2.1.1. $\left[{ }^{35} S\right] G T P \gamma S$ binding assay studies. The $\left[{ }^{35} \mathrm{~S}\right] \mathrm{GTP} \gamma \mathrm{S}$ binding was increased by $\mathrm{E} 2$ in a concentration dependent manner, which was reduced by mifepristone (Fig. 8 and Table 4).

3.2.1.2. cAMP study. E2 increased the level of cAMP in the uterine tissue compared to the control in high concentrations, while it had no effect in a low dose. The pre-treatment with mifepristone reduced the high E2 concentration-induced cAMP increase ( $\mathrm{p}<0.01)$, but mifepristone had no action in the case of low E2 concentration (Fig. 9).

\subsection{Progesterone}

P4 had a negligible effect on KCl-stimulated uterine contractions. The presence of mifepristone did not modify its action (Figs. 10, 11, Table 5). Since the relaxing effect of P4 was missing, we did not investigate it further.

\section{Discussion}

The non-genomic action of sex steroids on different tissues, especially on smooth muscles from different organs, has been investigated in several studies. It was proved that E2 and P4 had a vasorelaxant action through a non-genomic pathway. Studies on rat arterial beds showed that E2 induced vascular relaxation [17]. The same results were found on the arterial tissues in human [18,19] lamb [20], monkey [21] and mice [12]. On the contrary, the non-genomic action of E2 induced hyperreactivity and contraction on tracheal smooth muscles [22]. Additionally, E2 elicited non-genomic vasoconstriction in mice, which led to the reduction of skin cooling action [23]. The non-genomic smooth muscle relaxing effect of $\mathrm{T}$ was proved in human coronary arteries [24], umbilical arteries [25,26], peripheral vasculature of rats [27] and even in the trachea of guinea pigs $[28,29]$. However, a comparative investigation of the non-genomic effect of sex hormones on pregnant uterine contractions has not been carried out yet.

Therefore, we aimed to investigate the effects of the 3 basic sex hormones (E2, P4 and T) on pregnant uterine contractions on the last day of pregnancy in rats in vitro. E2 and T elicited a significant reduction in uterine contractions, while $\mathrm{P} 4$ was ineffective. The exposure time of the uterine tissues to the sex hormones was less than $30 \mathrm{~min}$, which is considered to be too short to initiate the genomic response [30]. We also proved this, since the blockade of the genomic pathway by the RNA transcription inhibitor actinomycin D and the protein synthesis inhibitor cycloheximide did not modify the effects of E2 or T. Subsequently, the removal of the endometrium did not modify the sex hormone effects either, so we also proved that the relaxation effects of $\mathrm{E} 2$ and T has a myometrial site of action. Surprisingly, both E2 and T had a remarkable relaxing effect (approximately 70\% inhibition). Although such an action of $\mathrm{T}$ was described earlier on human and pregnant rat uteri [31] [32], such a result about E2 has not been published yet. In contrast, E2, T and P4 were reported as ineffective on both pregnant rat and human myometrial contractions induced by oxytocin in vitro [33], but in that study the sex steroids were used in lower concentrations (below $10^{-6} \mathrm{M}$ ), while we applied them in $10^{-4}$ or $10^{-3} \mathrm{M}$ as the highest concentrations. Thus, the high concentrations can explain why we could detect quite a strong relaxing effect with $\mathrm{T}$ and E2. The other surprise was the ineffectiveness of $\mathrm{P} 4$ on pregnant contractions considering its clinical use against premature contractions 
in threatening preterm birth [34], although in that case it is applied as a preventive agent. Our result suggests that there is no prompt relaxing action of P4 on pregnant uterine contractions. Similarly, earlier studies did not find any non-genomic relaxing effect for P4 either [35], although a synthetic $\mathrm{P} 4$ derivative, dydrogesterone was found to inhibit the pregnant myometrial contractions by the inhibition of voltage dependent Ca-channels [33]. Some other experiments found that P4 had an ability to relax human non-pregnant or pregnant uterine tissues in high dose [36-38] which findings are virtually in conflict of our results. However, the findings may be a result of genomic feature of P4 since the P4 incubation period in both reported studies were more than $1 \mathrm{~h}$.

The specific receptor antagonists of sex hormones (flutamide for $\mathrm{T}$ and fulvestrant for E2) did not reduce their actions, which is further evidence that the genomic pathway is not involved in the relaxing effects of T and E2. Surprisingly, the actions of T and E2 were mifepristone sensitive, their maximum effects were reduced significantly by the compound. This suggests that mifepristone generally inhibits the nongenomic target of sex steroids for uterus relaxation, which is possibly independent of its progesterone and glucocorticoid receptor inhibitory action. The G protein coupled estrogen receptor (GPER or GPR30), which is coupled to Gs protein and enhances the intracellular cAMP level, has already been identified as a target of sex steroids in several tissues [39,40] as well as in human myometrium [41]. In our $\left[{ }^{35} \mathrm{~S}\right] \mathrm{GTP} \gamma \mathrm{S}$ binding and cAMP measurements we proved a significant increase in G-protein and cAMP levels after stimulation by T and E2, and their effects could be inhibited by mifepristone. The previously reported signaling pathway for putative sex steroid membrane receptors involves phospholipase, kinase [42], calcium [43] and other second messengers such as IP3 or cAMP [44]. It is also possible that the activation of a $\mathrm{G}$ protein receptor by rising cAMP regulates the voltagegated ion channels (e.g. $\mathrm{BK}_{\mathrm{Ca}}$ and $\mathrm{K}_{\mathrm{V}}$ ) [26] and the intracellular calcium regulation $[11,22]$. Our results suggest that $\mathrm{T}$ and $\mathrm{E} 2$ possibly activate GPR30 and mifepristone might be a competitive antagonist on this receptor.

\section{Conclusion}

$\mathrm{T}$ and $\mathrm{E} 2$ can significantly inhibit KCl-stimulated contractions in the late pregnant uterus in high concentrations and in a non-genomic manner. Their actions are mediated by a G-protein coupled receptor (possibly GPR30) that can be blocked by mifepristone. However, P4 seems to be inefficient as a non-genomic relaxant of pregnant uteri. Based on our results, a single and high dose of T or E2 might be considered in premature contractions, however, further preclinical and clinical studies are required for the approval of such a therapeutic intervention.

\section{Declaration of competing interest}

No competing interest.

\section{Acknowledgment}

This work was supported by the Ministry of Human Capacities. [Hungary grant 20391-3/2018/FEKUSTRAT] and the Stipendium Hungaricum Scholarship. Special thanks are due to Ágnes Csiszárné for technical assistance in the experiments.

\section{References}

[1] T. Sato, S. Miyagawa, T. Iguchi, Progesterone, in: Y. Takei, H. Ando, K.B.T.-H. of H. Tsutsui (Eds.), Handb. Horm, Elsevier, San Diego, 2016, , https://doi.org/10. 1016/B978-0-12-801028-0.00220-8 pp. 507-e94A-3.

[2] G.W. Corner, A. Csapo, Action of the ovarian hormones on uterine muscle, BMJ 1 (1953) 687-693, https://doi.org/10.1136/bmj.1.4812.687.

[3] M.A. Okon, S.M. Laird, E.M. Tuckerman, T.C. Li, Serum androgen levels in women who have recurrent miscarriages and their correlation with markers of endometrial function, Fertil. Steril. 69 (1998), https://doi.org/10.1016/S0015-0282(98) 00007-7.

[4] M. Beato, S. Chávez, M. Truss, Transcriptional regulation by steroid hormones, Steroids, Elsevier Inc, 1996, pp. 240-251, , https://doi.org/10.1016/0039-128X (96)00030-X.

[5] C.M. Szego, J.S. Davis, Adenosine 3',5'-monophosphate in rat uterus: acute elevation by estrogen, Proc. Natl. Acad. Sci. 58 (1967) 1711-1718, https://doi.org/10. 1073/pnas.58.4.1711.

[6] M. Nakashima, M. Suzuki, M. Saida, Y. Kamei, M.B. Hossain, T. Tokumoto, Cellbased assay of nongenomic actions of progestins revealed inhibitory $\mathrm{G}$ protein coupling to membrane progestin receptor $\alpha(\mathrm{mPR} \alpha)$, Steroids 100 (2015) 21-26, https://doi.org/10.1016/j.steroids.2015.04.002.

[7] T. Mitsui, M. Ishida, M. Izawa, J. Arita, Activation of G protein-coupled estrogen receptor 1 mimics, but does not mediate, the anti-proliferative action of estradiol on pituitary lactotrophs in primary culture, Endocr. J. 64 (2017) 103-115, https://doi. org/10.1507/endocrj.EJ16-0079.

[8] A. Romarowski, C. Sánchez-Cárdenas, H.V. Ramírez-Gómez, L. del C. Puga Molina, C.L. Treviño, A. Hernández-Cruz, A. Darszon, M.G. Buffone, A specific transitory increase in intracellular calcium induced by progesterone promotes acrosomal exocytosis in mouse Sperm1, Biol. Reprod. 94 (2016) 136085, https://doi.org/10. 1095/biolreprod.115.136085.

[9] K. Barabás, S. Godó, F. Lengyel, D. Ernszt, J. Pál, I.M. Ábrahám, Rapid non-classical effects of steroids on the membrane receptor dynamics and downstream signaling in neurons, Horm. Behav. 104 (2018) 183-191, https://doi.org/10.1016/j.yhbeh. 2018.05.008.

[10] J. Kurokawa, M. Kodama, C.E. Clancy, T. Furukawa, Sex hormonal regulation of cardiac ion channels in drug-induced QT syndromes, Pharmacol. Ther. 168 (2016) 23-28, https://doi.org/10.1016/j.pharmthera.2016.09.004.

[11] M. Perusquía, N. Herrera, M. Ferrer, J.N. Stallone, Antihypertensive effects of androgens in conscious, spontaneously hypertensive rats, J. Steroid Biochem. Mol. Biol. 167 (2017) 106-114, https://doi.org/10.1016/j.jsbmb.2016.11.016.

[12] M.R. Meyer, N.C. Fredette, T.A. Howard, C. Hu, C. Ramesh, C. Daniel, K. Amann, J.B. Arterburn, M. Barton, E.R. Prossnitz, G protein-coupled estrogen receptor protects from atherosclerosis, Sci. Rep. 4 (2015) 7564, https://doi.org/10.1038/ srep07564.

[13] M. Barton, E.R. Prossnitz, Emerging roles of GPER in diabetes and atherosclerosis, Trends Endocrinol. Metab. 26 (2015) 185-192, https://doi.org/10.1016/j.tem. 2015.02.003.

[14] S.R. Hammes, E.R. Levin, Extranuclear steroid receptors: nature and actions, Endocr. Rev. 28 (2007) 726-741, https://doi.org/10.1210/er.2007-0022.

[15] A. Kothencz, J. Hajagos-Tóth, K.F. Szúcs, A. Schaffer, R. Gáspár, $\alpha$-Tocopherol potentiates the cervical resistance decreasing effects of COX inhibitors in pregnant rats: the putative role of cyclooxygenase-2 inhibition, J. Pharmacol. Exp. Ther. 368 (2019) 292-298, https://doi.org/10.1124/jpet.118.251850.

[16] E. Szucs, A. Büki, G. Kékesi, G. Horváth, S. Benyhe, Mu-opioid (MOP) receptor mediated G-protein signaling is impaired in specific brain regions in a rat model of schizophrenia, Neurosci. Lett. 619 (2016) 29-33, https://doi.org/10.1016/j.neulet. 2016.02.060.

[17] R.H.P. Hilgers, S. Oparil, W. Wouters, H.J.T. Coelingh Bennink, Vasorelaxing effects of estetrol in rat arteries, J. Endocrinol. 215 (2012) 97-106, https://doi.org/10. 1530/JOE-12-0009.

[18] E. Haas, I. Bhattacharya, E. Brailoiu, M. Damjanovic, G.C. Brailoiu, X. Gao, L. Mueller-Guerre, N.A. Marjon, A. Gut, R. Minotti, M.R. Meyer, K. Amann, E. Ammann, A. Perez-Dominguez, M. Genoni, D.J. Clegg, N.J. Dun, T.C. Resta, E.R. Prossnitz, M. Barton, Regulatory role of G protein-coupled estrogen receptor for vascular function and obesity, Circ. Res. 104 (2009) 288-291, https://doi.org/ 10.1161/CIRCRESAHA.108.190892.

[19] K.S. Russell, M.P. Haynes, D. Sinha, E. Clerisme, J.R. Bender, Human vascular endothelial cells contain membrane binding sites for estradiol, which mediate rapid intracellular signaling, Proc. Natl. Acad. Sci. U. S. A. 97 (2000) 5930-5935, https:// doi.org/10.1073/pnas.97.11.5930.

[20] Z. Chen, I.S. Yuhanna, Z. Galcheva-Gargova, R.H. Karas, M.E. Mendelsohn, P.W. Shaul, Estrogen receptor mediates the nongenomic activation of endothelial nitric oxide synthase by estrogen, J. Clin. Invest. 103 (1999) 401-406, https://doi. org/10.1172/JCI5347.

[21] R.D. Minshall, D. Pavcnik, D.L. Browne, K. Hermsmeyer, Nongenomic vasodilator action of progesterone on primate coronary arteries, J. Appl. Physiol. 92 (2002) 701-708, https://doi.org/10.1152/japplphysiol.00689.2001.

[22] E. Flores-Soto, I. Martínez-Villa, H. Solís-Chagoyán, B. Sommer, C. Lemini, L.M. Montaño, 17ß-Aminoestrogens induce guinea pig airway smooth muscle hyperresponsiveness through L-type Ca2 + channels activation, Steroids 101 (2015) 64-70, https://doi.org/10.1016/j.steroids.2015.06.001.

[23] I. Serizawa, N. Iwasaki, H. Ishida, S. Saito, T. Ishikawa, G-protein coupled estrogen receptor-mediated non-genomic facilitatory effect of estrogen on cooling-induced reduction of skin blood flow in mice, Eur. J. Pharmacol. 797 (2017) 26-31, https:// doi.org/10.1016/j. ejphar.2017.01.013.

[24] K. Ruamyod, W.B. Watanapa, C. Shayakul, Testosterone rapidly increases $\mathrm{Ca}(2+)$ activated $\mathrm{K}(+)$ currents causing hyperpolarization in human coronary artery endothelial cells, J. Steroid Biochem. Mol. Biol. 168 (2017) 118-126, https://doi.org/ 10.1016/j.jsbmb.2017.02.014.

[25] P.A. Saldanha, E. Cairrão, C.J. Maia, I. Verde, Long- and short-term effects of androgens in human umbilical artery smooth muscle, Clin. Exp. Pharmacol. Physiol. 40 (2013) 181-189, https://doi.org/10.1111/1440-1681.12047.

[26] J. Feiteiro, A.J. Santos-Silva, I. Verde, E. Cairrão, Testosterone and atrial natriuretic peptide share the same pathway to induce vasorelaxation of human umbilical artery, J. Cardiovasc. Pharmacol. 63 (2014) 461-465, https://doi.org/10.1097/FJC. 
0000000000000060

[27] M. Perusquía, C.D. Greenway, L.M. Perkins, J.N. Stallone, Systemic hypotensive effects of testosterone are androgen structure-specific and neuronal nitric oxide synthase-dependent, Am. J. Physiol. - Regul. Integr. Comp. Physiol. 309 (2015) R189-R195, https://doi.org/10.1152/ajpregu.00110.2015.

[28] E. Flores-Soto, J. Reyes-García, A. Carbajal-García, E. Campuzano-González, M. Perusquía, B. Sommer, L.M. Montaño, Sex steroids effects on guinea pig airway smooth muscle tone and intracellular $\mathrm{Ca}^{2+}$ basal levels, Mol. Cell. Endocrinol. 439 (2017) 444-456, https://doi.org/10.1016/j.mce.2016.10.004.

[29] L.M. Montaño, E. Flores-Soto, J. Reyes-García, V. Díaz-Hernández, A. CarbajalGarcía, E. Campuzano-González, G.L. Ramírez-Salinas, M.A. Velasco-Velázquez, B. Sommer, Testosterone induces hyporesponsiveness by interfering with IP3 receptors in guinea pig airway smooth muscle, Mol. Cell. Endocrinol. 473 (2018) 17-30, https://doi.org/10.1016/j.mce.2017.12.010.

[30] A.K.L. Herald, R. Alves-Lopes, A.C. Montezano, S.F. Ahmed, R.M. Touyz, Genomic and non-genomic effects of androgens in the cardiovascular system: clinical implications, Clin. Sci. 131 (2017) 1405-1418, https://doi.org/10.1042/CS20170090.

[31] M. Perusquía, E. Navarrete, J. Jasso-Kamel, L.M. Montaño, Androgens induce relaxation of contractile activity in pregnant human myometrium at term: a nongenomic action on L-type calcium Channels1, Biol. Reprod. 73 (2005) 214-221, https://doi.org/10.1095/biolreprod.104.036954.

[32] Z. Yin, Y. Li, W. He, D. Li, H. Li, Y. Yang, B. Shen, X. Wang, Y. Cao, R.A. Khalil, Progesterone inhibits contraction and increases TREK-1 potassium channel expression in late pregnant rat uterus, Oncotarget 9 (2018) 651-661, https://doi.org/ 10.18632/oncotarget.23084.

[33] K. Yasuda, G. Sumi, H. Murata, N. Kida, T. Kido, H. Okada, The steroid hormone dydrogesterone inhibits myometrial contraction independently of the progesterone/ progesterone receptor pathway, Life Sci. 207 (2018) 508-515, https://doi.org/10. 1016/j.lfs.2018.07.004.

[34] V. Berghella, Progesterone and preterm birth prevention: translating clinical trials data into clinical practice, Am. J. Obstet. Gynecol. 206 (2012) 376-386, https:// doi.org/10.1016/j.ajog.2012.03.010.

[35] J. Baumbach, S.Q. Shi, L. Shi, J. Balducci, D.V. Coonrod, R.E. Garfield, Inhibition of uterine contractility with various tocolytics with and without progesterone: In vitro studies, Am. J. Obstet. Gynecol, Mosby Inc, 2012, pp. 254.e1-254.e5, , https://doi. org/10.1016/j.ajog.2011.12.011

[36] T.A. Orth, S.Q. Shi, K. Williamson, L. Shi, L. Chambliss, D.V. Coonrod, J. Balducci, R.E. Garfield, Additive inhibitory effects of progesterone and sodium nitroprusside on uterine contractility during pregnancy, Reprod. Sci. 18 (2011) 868-875, https:// doi.org/10.1177/1933719111398141.

[37] M. Lucovnik, R.J. Kuon, L.R. Chambliss, W.L. Maner, S.-Q. Shi, L. Shi, J. Balducci, R.E. Garfield, Progestin treatment for the prevention of preterm birth, Acta Obstet. Gynecol. Scand. 90 (2011) 1057-1069, https://doi.org/10.1111/j.1600-0412. 2011.01178.x.

[38] A. Kostrzewska, T. Laudánski, S. Batra, Effect of ovarian steroids and diethylstilbestrol on the contractile responses of the human myometrium and intramyometrial arteries, Eur. J. Pharmacol. 233 (1993) 127-134, https://doi.org/10. 1016/0014-2999(93)90358-0.

[39] M. Barton, E.J. Filardo, S.J. Lolait, P. Thomas, M. Maggiolini, E.R. Prossnitz, Twenty years of the G protein-coupled estrogen receptor GPER: historical and personal perspectives, J. Steroid Biochem. Mol. Biol. (2017) 1-12, https://doi.org/10.1016/ j.jsbmb.2017.03.021.

[40] S.H. Lindsey, K. a Carver, E.R. Prossnitz, M.C. Chappell, Vasodilation in response to the GPR30 agonist G-1 is not different from estradiol in the mRen2.Lewis female rat, J. Cardiovasc. Pharmacol. 57 (2011) 598-603, https://doi.org/10.1097/FJC. 0b013e3182135flc.

[41] K. Maiti, J.W. Paul, M. Read, E.C. Chan, S.C. Riley, P. Nahar, R. Smith, G-1-activated membrane estrogen receptors mediate increased contractility of the human myometrium, Endocrinology 152 (2011) 2448-2455, https://doi.org/10.1210/en. 2010-0979.

[42] N. Schwartz, A. Verma, C.B. Bivens, Z. Schwartz, B.D. Boyan, Rapid steroid hormone actions via membrane receptors, Biochim. Biophys. Acta - Mol. Cell Res. 1863 (2016) 2289-2298, https://doi.org/10.1016/j.bbamcr.2016.06.004.

[43] N.E. Vega-Vela, D. Osorio, M. Avila-Rodriguez, J. Gonzalez, L.M. García-Segura, V. Echeverria, G.E. Barreto, L-type calcium channels modulation by estradiol, Mol. Neurobiol. 54 (2017) 4996-5007, https://doi.org/10.1007/s12035-016-0045-6.

[44] M.L. Oróstica, J. Lopez, I. Rojas, J. Rocco, P. Diáz, P. Reuqueń, H. Cardenas, A. Parada-Bustamante, P.A. Orihuela, Estradiol increases cAMP in the oviducta secretory cells through a nongenomic mechanism, Reproduction 148 (2014) 285-294, https://doi.org/10.1530/REP-14-0128. 